\title{
Antibacterial, antioxidant, and cytotoxic activities of the corticolous lichens Canoparmelia aptata, Pannaria sp., and Parmotrema gardneri collected from Mt. Banahaw, Quezon, Philippines
}

\author{
De Jesus $\mathrm{EE}^{1,2,3}$, Hur $\mathrm{JS}^{4}$, Notarte $\mathrm{KIR}^{2,3}$, Santiago $\mathrm{KAA}^{5}$ and dela Cruz $\mathrm{TEE}^{2,3}$ \\ ${ }^{1}$ College of Arts and Sciences, Southern Luzon State University, Lucban 4328 Quezon, Philippines \\ ${ }^{2}$ The Graduate School, University of Santo Tomas, España 1008 Manila, Philippines \\ ${ }^{3}$ Fungal Biodiversity and Systematics Group, Research Center for the Natural and Applied Sciences, University of Santo \\ Tomas, España 1008 Manila, Philippines \\ ${ }^{4}$ Korean Lichen Research Institute, Sunchon National University, Sunchon 540-742, South Korea \\ ${ }^{5}$ Department of Biological Sciences, Institute of Arts and Sciences, Far Eastern University, Sampaloc 1015 Manila, \\ Philippines
}

De Jesus EE, Hur JS, Notarte KIR, Santiago KAA, dela Cruz TEE 2016 - Antibacterial, antioxidant, and cytotoxic activities of the corticolous lichens Canoparmelia aptata, Pannaria sp., and Parmotrema gardneri collected from Mt. Banahaw, Quezon, Philippines. Current Research in Environmental \& Applied Mycology 6(3), 173-183, Doi 10.5943/cream/6/3/4

\begin{abstract}
Lichens are remarkable sources of bioactive secondary metabolites with potential chemotherapeutic properties. In this study, we evaluated the bioactivities of three corticolous lichens collected from Mount Banahaw in Quezon Province, Philippines. The lichens Parmotrema gardneri, Pannaria sp., and Canoparmelia aptata were extracted with acetone and assayed for cytotoxicity, and antibacterial and antioxidant activities. Results showed that the lichen extracts of $P$. gardneri, Pannaria sp. and $C$. aptata were either active (13-19 mm, zone of inhibition, ZOI) or partially active (10-12 mm ZOI) against Pseudomonas aeruginosa and Staphylococcus aureus. For the cytotoxicity assay, $P$. gardneri had the lowest inhibition concentration $\left(\mathrm{IC}_{50}\right.$ ) values of 12.29 and $20.24 \mu \mathrm{g} / \mathrm{mL}$ for the human gastric adenocarcinoma (AGS) and human lung carcinoma (A549), respectively. The same lichen extract rendered selectivity with $\mathrm{IC}_{50}$ of $66.35 \mu \mathrm{g} / \mathrm{mL}$ against the normal Madin Darby Canine Kidney (MDCK) cell lines. The extracts yielded low radical scavenging activity of less than $40 \%$ and generated low amounts of $\mathrm{FeSO}_{4}$ per milligram sample. Metabolic profiling detected the presence of protocetraric acid, usnic acid, zeorin, atranorin, chloroatranorin, and galbinic acid.
\end{abstract}

Keywords - chemotherapeutic - foliose lichens - secondary metabolites - selectivity

\section{Introduction}

Lichens represent an essentially stable, self-supporting association between two distinct entities a fungus (the mycobiont) and a photosynthetic partner (the photobiont), which can be an alga, a cyanobacterium or both. The number of lichens worldwide are believed to range from 13,500 to 17,000 species (Deacon 2006). However, recent studies by Lücking et al. (2009) and Thell et al. (2012) estimated the number of lichen species worldwide to be approximately 28,000 . This is mainly due to an increase in research activity on lichens in tropical regions where, perhaps, many of the undocumented lichens can be found. The Philippines is a mega-diverse country when it comes to the variety of 
ecosystems, species, and genetic resources. The country harbors a diverse lichen flora, especially corticolous lichens, but studies to date are very few. This paper contributes to the documentation of lichens, particularly the corticolous lichens, in the country.

Over the past two decades, there is also a growing interest in the study of lichens as possible sources of novel, pharmacologically active biomolecules (Zambare \& Christopher 2012). These bioactive compounds can be tapped for chemotherapeutic uses (Ranković et al. 2011, Kosanić \& Ranković 2015). In fact, structures of more than 1,050 different lichen substances have already been reported (Molnar \& Farkas 2010). Thus, repetitive investigations on lichens can reveal the presence of metabolites with antipyretic (Kumar 2010, Süleyman et al. 2003), analgesic (Omarsdóttir et al. 2007), antioxidant (Styers \& Chappelka 2009), cytotoxic (Nguyen et al. 2014), and antimicrobial (Ranković et al. 2011, Santiago et al. 2010, 2013) activities. Given their potential, the study herein aimed to investigate the antibacterial, antioxidant, and cytotoxic activities of the corticolous lichens Canoparmelia aptata, Pannaria sp., and Parmotrema gardneri collected from Mount Banahaw in Quezon Province, Philippines.

\section{Materials \& Methods}

\section{Collection of corticolous lichens}

The lichen thalli of Canoparmelia aptata, Pannaria sp., and Parmotrema gardneri were collected at an elevation of 700 meter above sea level (masl) in Mount Banahaw de Lucban in Quezon Province, Luzon Island, Philippines (14\% $\left.4^{\prime} 17^{\prime} \mathrm{N}, 121^{\circ} 29^{\prime} 32^{\prime \prime} \mathrm{E}\right)$. It is bounded by Laguna Lake on the north, Tayabas Bay on the south, Bicol Peninsula on the southeast, and the tail end of the Sierra Madre Mountain on the east (Gascon et al. 2013). The permit to collect the lichen specimens was issued by the provincial office of the Department of Environment and Natural Resources (DENR). The lichen samples were then air-dried at room temperature and stored as voucher specimens until used in the study. Representative voucher specimens were deposited at the Pure and Applied Microbiology Laboratory, Research Center for the Natural and Applied Sciences, University of Santo Tomas in Manila, Philippines.

\section{Identification of lichens}

Morphoanatomical Characterization and Thalline Spot Test. Identification of the lichen species was initially done based on their morphoanatomical characters. Characters such as growth forms, color, and texture of the lichen thalli, and the descriptions of their fruiting bodies, e.g. the shape, attachment, margin, and size of apothecia or perithecia, were observed under a dissecting microscope (Olympus, Omnibus Biomedical Systems). Thalline spot test was also done using the reagents potassium hydroxide (K), sodium hypochlorite (C), and iodide (I) following the protocol of Culberson (1972). The reagents were spotted on a small fragment of the lichen thalli. Any change in color indicates the presence of lichen acids. Then, the morphoanatomical characters and results of the thalline spot tests were compared with published literature, i.e. Aptroot (2009), Lücking et al. (2009), McCune (2012), and Nayaka (2014), for the identification of the lichens.

Molecular Identification. To confirm the identity of the collected lichens, the genomic DNA was extracted as described by Park et al. (2014). About $100 \mathrm{mg}$ of the air-dried lichen thalli were placed together with three to four $2.5 \mathrm{~mm}$ sterile glass beads in XXTuff Reinforced Microvial (Biospec, USA). This was placed in liquid nitrogen and then pulverized for 30 seconds with a Mini Bead beater-24 (Biospec, USA). The procedure was repeated until the samples turned into a fine powder. The powdered lichen thalli were mixed vigorously with $300 \mu \mathrm{L} \mathrm{KCl}$ extraction buffer. The solution was again mixed with $300 \mu \mathrm{L}$ chloroform, gently shaken for 20 times, and then centrifuged for 1 minute at $12,000 \mathrm{rpm}$ at room temperature. The upper aqueous layer was transferred to a new microcentrifuge tube, to which $180 \mu \mathrm{L}$ chilled isopropanol was added, and the mixture was gently mixed and centrifuged for 1 minute at $12,000 \mathrm{rpm}$. The supernatant was discarded and the resulting pellets were then washed with $300 \mu \mathrm{L}$ chilled $70 \%$ ethanol and oven-dried at $50 \sim 65{ }^{\circ} \mathrm{C}$ for 5 minutes. The pellets were subsequently re-suspended in a $100 \mu \mathrm{L}$ TE buffer $(1 \mathrm{X})$ at $50 \sim 65{ }^{\circ} \mathrm{C}$, then oven-dried 
for 5 minutes. Purified DNA was stored at $4{ }^{\circ} \mathrm{C}$. The quality and quantity of extracted DNA were determined using an Epoch Multi-Volume Spectrophotometer System (BioTek, USA). Following the protocol of Park et al. (2014), PCR was used to amplify the internal transcribed spacer (ITS) regions of the rRNA genes using the primer pairs ITS1 (5'CTTGGTCATTTAGAGGAAGTA3') and ITS4 (5'TCCTCCGCTTATTGATATGA3') (White et al. 1990). The PCR reactions included $5 \mu \mathrm{L}$ of DNA sample, $2 \mu \mathrm{L}$ of each primer pair, and $13 \mu \mathrm{L}$ PCR mix. This was then run for 30 cycles in a Takara PCR thermal cycler. PCR conditions were set by denaturing the target double-stranded DNA fragment in the reaction mixture containing the primer, dNTP, and polymerase at $94{ }^{\circ} \mathrm{C}$ for 30 seconds followed by 30 cycles at $94{ }^{\circ} \mathrm{C}$ for 1 minute. Annealing then followed at $55{ }^{\circ} \mathrm{C}$ for 30 seconds and $72{ }^{\circ} \mathrm{C}$ for 1 minute, with a final extension at $72{ }^{\circ} \mathrm{C}$ for 10 minutes. The amplified PCR products were then purified using MEGAquick-spin Total Fragment DNA Purification Kit (iNtRON Biotechnology, Korea) prior to sequencing. Gene sequencing was done by Macrogen, Korea. The forward and reverse sequences were edited and combined using the MEGA 5.1 sequence assembly software. The generated sequences were submitted to GenBank (http:// www.ncbi.nlm.nih.gov/) to obtain related taxa. The published sequences, along with the sample lichen's sequences, were aligned and edited using BioEdit via the accessory application ClustalW multiple alignment. Lastly, the phylogenetic tree was constructed using MEGA5 software. The identity of the lichen samples was disclosed based on similarities of the related sequences.

\section{Extraction and detection of lichen acids}

Ten grams of air-dried lichen thalli of $C$. aptata, Pannaria sp., and P. gardneri were ground with mortar and pestle. The powdered thalli were dissolved with $100 \mathrm{~mL}$ acetone and were allowed to stand overnight. Following soaking, the lichen extracts were filtered and the filtrate was evaporated for four to five days to allow crystallization as previously described by Santiago et al. (2010). These crude extracts were dissolved in acetone to achieve a final concentration of $10 \mathrm{mg} / \mathrm{mL}$ and subsequently stored in the refrigerator until further use. Detection of lichen acids was conducted with thin layer chromatography (TLC) and high-performance liquid chromatography (HPLC). TLC was performed using the solvent system A [toluene: dioxane: glacial acetic acid (180:85:5)] following the methods of Orange et al. (2001). Lichen extracts were then spotted on TLC plate, run onto the solvent, and sprayed with $0.5 \mathrm{~mL}$ glacial acetic acid and $97 \%$ sulfuric acid. Then, the plates were heated at $105{ }^{\circ} \mathrm{C}$ for 5 minutes to visualize any lichen acids. Norstictic acid and atranorin of Letharia cladonioides served as controls. Furthermore, lichen acids were also detected using HPLC following the protocol of Nguyen et al. (2014). The lichen extracts were initially dissolved in $2 \mathrm{~mL}$ acetone and subsequently subjected to HPLC analysis (Shimadzu, Japan) using a reversed-phase column with C18 (particle size, $5 \mathrm{~mm}$; pore size, $12 \mathrm{~nm}$ ). For the HPLC, the column temperature was set at $40{ }^{\circ} \mathrm{C}$ and the flow rate was adjusted to $1 \mathrm{~mL}$ per minute. The solvent system used was methanol:water:phosphoric acid (80:20:1) and a photodiode array detector (SPD-M20A, 190-800nm) was used to run the HPLC. The peaks were detected and scanned between 190 and $400 \mathrm{~nm}$. In this study, the following standard lichen acids were used: salazinic acid (retention time $(\mathrm{tR})=2.27 \pm 0.2$ minute, from Lobaria pulmonaria), usnic acid (tR $=11.3 \pm 0.3$ minute, from Usnea longissima), protolichesterinic acid and lichesterinic acid $(\mathrm{tR}=22.3 \pm$ 0.2 minute and $\mathrm{tR}=26.5 \pm 0.2$ minute, respectively, from Cetraria islandica).

\section{Antibacterial activity}

Test bacteria. The test bacteria used were Staphylococcus aureus ATCC 25923, Pseudomonas aeruginosa ATCC 15692, and Escherichia coli ATCC 25922. These were obtained from the UST Collection of Microbial Strains (USTCMS), University of Santo Tomas in Manila, Philippines.

Paper Disk Diffusion Assay. In determining the effectiveness of the lichen extracts against the test bacteria, the paper disk diffusion assay was performed as previously described by Gasi et al. (2007). Pure cultures of $S$. aureus, P. aeruginosa, and E. coli were inoculated into $5 \mathrm{~mL} 0.85 \%$ Normal Saline Solution. The bacterial suspensions were adjusted to $0.5 \mathrm{McFarland}$ Standard (equivalent to 1.5 x $10^{8} \mathrm{CFU} / \mathrm{mL}$ ) and swabbed aseptically onto 4-mm deep Mueller Hinton Agar (MHA). Sterile paper disks in triplicates (6 $\mathrm{mm}$ in diameter) were impregnated with $25 \mu \mathrm{L}$ of crude extract at a screening 
concentration of $10 \mathrm{mg} / \mathrm{mL}$. The positive controls were ampicillin for $S$. aureus, gentamycin for $P$. aeruginosa, and tetracycline for $E$. coli, while acetone and distilled water served as the negative controls. The treated disks were dried for 1 hour at $80{ }^{\circ} \mathrm{C}$ and placed on top of each swabbed MHA. The assay was performed in triplicates. All culture plates were incubated for $18-24$ hours at $37{ }^{\circ} \mathrm{C}$. The zone of inhibition (ZOI) was measured using a vernier caliper and assessed following Quinto \& Santos (2005): (1) very active, > $19 \mathrm{~mm}$ ZOI, (2) active, 13-19 mm ZOI, (3) partially active, 10-12 mm ZOI, and (4) inactive, $<10 \mathrm{~mm}$ ZOI. T-test was computed between ZOI of the test extracts and the control antibiotics to determine significant differences.

\section{Cytotoxic Activity}

Cell Lines. The human gastric adenocarcinoma (AGS) and human lung carcinoma (A549) cell lines were obtained from the Korean Cell Line Bank, Korea. These were maintained in Roswell Park Memorial Institute (RPMI) 1640 medium (Gen Depot, USA) containing 10\% heat-inactivated fetal bovine serum, $1 \%$ penicillin and streptomycin, $3 \mathrm{mM}$ L-glutamine, and $25 \mathrm{mM}$ HEPES adjusted to $\mathrm{pH}$ 7.2. The Madin-Darby Canine Kidney (MDCK) cells were cultivated in Dulbecco's Modified Eagle Medium (DMEM) (Gen Depot, USA) containing 10\% fetal bovine serum and 1\% streptomycin and penicillin. The full-grown cells were maintained in an atmosphere of $5 \% \mathrm{CO}_{2}$ at $37^{\circ} \mathrm{C}$.

MTT assay. The lichen extracts were dissolved in DMSO and successively diluted with DMEM to prepare different test concentrations: $6.125,12.5,25,50,100$ and $200 \mathrm{mg} / \mathrm{mL}$. Afterwards, the cells $\left(2 \times 10^{4}\right.$ cells/well) were added on a 96-well plate, grown overnight, and then treated with the lichen extracts of C. aptata, Pannaria sp., and P. gardneri for 48 hours. Upon completion of the treatment, MTT saline solution was added and further incubated for 4 hours at $37{ }^{\circ} \mathrm{C}$ in $5 \% \mathrm{CO}_{2}$. In extracting formazan, $100 \mu \mathrm{L}$ of $20 \%$ Sodium Dodecyl Sulfate (SDS) was added resulting from the conversion of the MTT dye by viable cells. Incubation followed for 10 minutes upon the addition of 50\% DMSO. Thereafter, absorbance was measured at $570 \mathrm{~nm}$ using a microplate reader (VERSAmax, Molecular Devices, USA). The assay was performed in triplicates and a dose-dependent curve was plotted in GraphPad Prism 5 software for $\mathrm{IC}_{50}$ determination.

\section{Antioxidant activity}

Assay for radical scavenging activity (RSA). The lichen extracts were initially dissolved in methanol to a final concentration of $500 \mathrm{ppm}$. A $0.1 \mathrm{mM} \mathrm{DPPH}$ solution in $\mathrm{MeOH}$ was freshly prepared by diluting $1 \mathrm{~mL}$ DPPH stock solution $(3.49 \mathrm{mg}$ DPPH in $1 \mathrm{~mL} \mathrm{MeOH}$ ) to $100 \mathrm{~mL} \mathrm{MeOH}$. One $\mathrm{mL}$ of each of the lichen extracts and $4 \mathrm{~mL}$ of the DPPH solution were mixed and incubated in the dark at $37{ }^{\circ} \mathrm{C}$ for 30 minutes. The assay was performed in triplicates. Following incubation, the absorbance reading was monitored at $517 \mathrm{~nm}$ using APEL100 UV-Vis spectrophotometer (PD-303UV, Japan). Finally, the ability to scavenge the DPPH radical was calculated using the equation: \% DPPH scavenging effect $=\left[\left(\mathrm{A}_{\text {control }}-\mathrm{A}_{\text {sample }}\right) / \mathrm{A}_{\text {control }}\right] \times 100$, where $\mathrm{A}_{\text {control }}$ is the absorbance of the control (DPPH solution without the crude lichen extract), and $\mathrm{A}_{\text {sample }}$ is the absorbance of the test sample containing the mixture of DPPH and the crude lichen extract. The synthetic antioxidant Vitamin E was used as positive control (Abichandani et al. 2010).

Assay for Ferric Reducing Antioxidant Power (FRAP). A $0.2 \mathrm{~mL}$ aliquot of lichen extracts with the following concentrations of $0.125,0.25,0.50$ and $1.00 \mathrm{mg} / \mathrm{mL}$ were added to $3.8 \mathrm{~mL}$ of FRAP reagent [10 parts of $300 \mathrm{mM}$ sodium acetate buffer at $\mathrm{pH} 3.6,1$ part $10 \mathrm{mM}$ TPTZ (2,4,6-tripyridyl-striazine) solution, 1 part $20 \mathrm{mM} \mathrm{FeCl} 3 \cdot 6 \mathrm{H}_{2} \mathrm{O}$ solution]. This was incubated at $37^{\circ} \mathrm{C}$ for 30 minutes. Absorbance was measured at $593 \mathrm{~nm}$. Fresh working solutions of $\mathrm{FeSO}_{4}$ were used as standard. Results

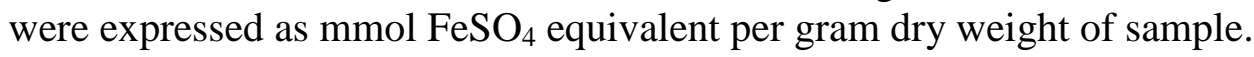

\section{Results}

The foliose lichens Canoparmelia aptata, Pannaria sp., and Parmotrema gardneri collected at an elevation of 700 masl of Mt. Banahaw de Lucban, Quezon Province were used in this study (Fig. 1). Canoparmelia aptata is described as whitish to gray thallus that measures $3-7 \mathrm{~cm}$ with $5.86 \mathrm{~mm}$ average lobe width. The soredia measured $4.55 \mathrm{~mm}$, and the ascospores ranged from 7-20 $\times 4-9 \mu \mathrm{m}$. 
Phylogenetic analysis provided a 100\% bootstrap support confirming the identity of this lichen (Fig. 2). The detected lichen metabolites of $C$. aptata included protocetraric acid, atranorin, and chloroatranorin (Fig. 3). Usnic acid and zeorin were also detected via TLC. Pannaria sp. is described as a foliose lichen with a bluish gray to olive gray upper surface color, forming orbicular rosettes, with a thallus size of 2$3 \mathrm{~cm}$. The lobes are mostly concave, having whitish margins and with a width of 3-4 mm. It has a frequent centrally located apothecia measuring $0.53 \mathrm{~mm}$ and with a simple, colorless ascospores ranging from 8-10 x 15-20 $\mu \mathrm{m}$. However, the identities of the lichen acids detected in this species were unknown (Fig. 3). The specimen used in this study could not also be identified with full certainty by phylogenetic analysis. The sequences clustered with the other Pannaria, albeit with a low bootstrap support (Fig. 2). Parmotrema gardneri is recognized by its adnate, pale grayish green thalli with common marginal granular soralia. The thalli measure $2-3 \mathrm{~cm}$ while its lobe is about $5.34 \mathrm{~mm}$ wide. Apothecia are present with a size of $2.72 \mathrm{~mm}$ and has ascospores ranging from 18-22 x 10-15 $\mu \mathrm{m}$. Rhizines are sparsely at the center while almost lacking at the marginal zone of the thalli. $P$. gardneri had galbinic acid, atranorin, and chloroatranorin (Fig. 3). This species was not subjected to molecular identification.
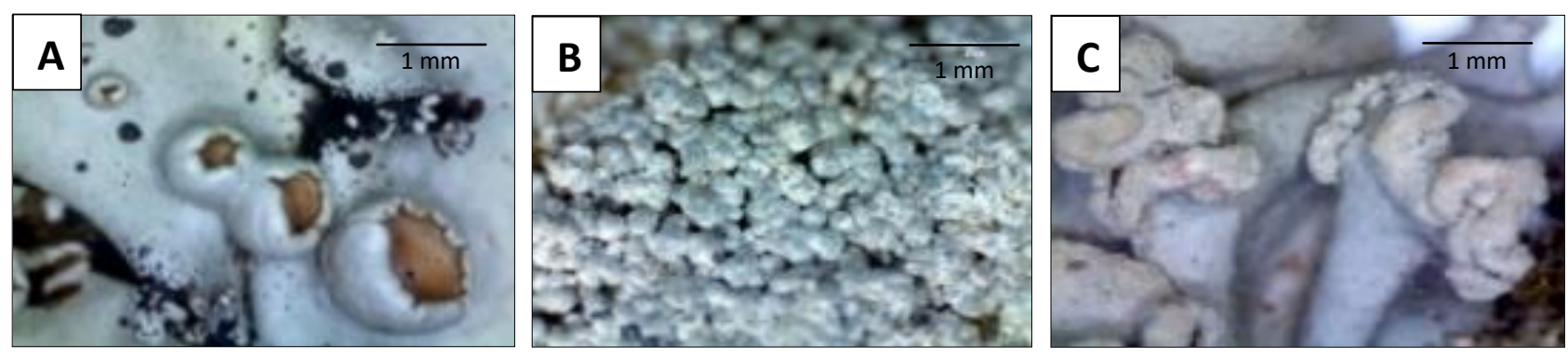

Fig. 1 - Thallus structure of C. aptata (A), Pannaria sp. (B), and P. gardneri (C). Scale bar $=1 \mathrm{~mm}$.
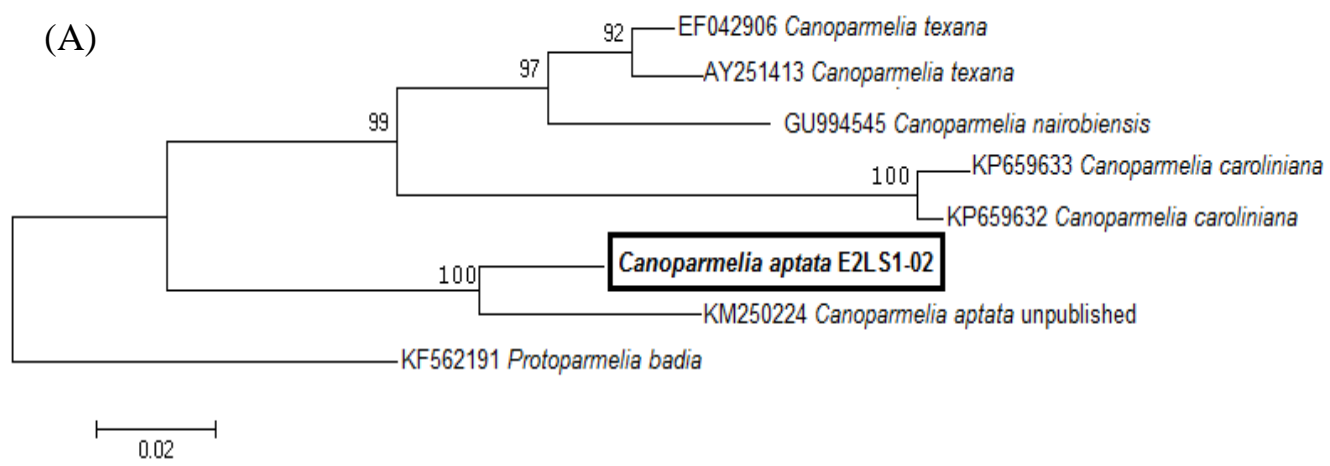

(B)

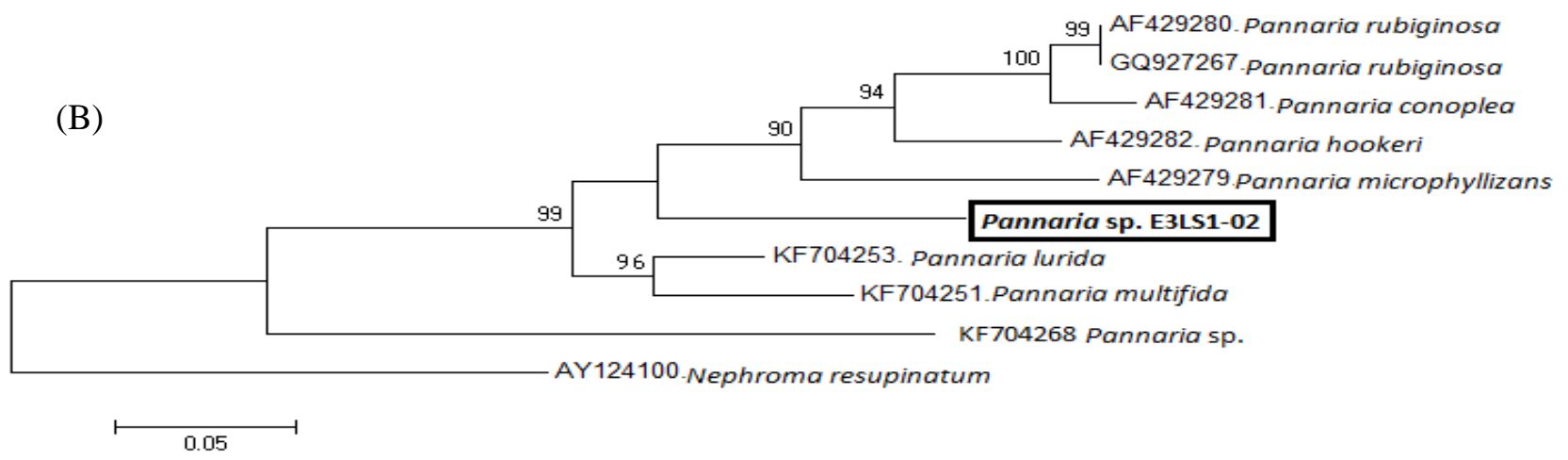

Fig. 2 - Phylogenetic trees of C. aptata (A) and Pannaria sp. (B) based on maximum parsimony. 

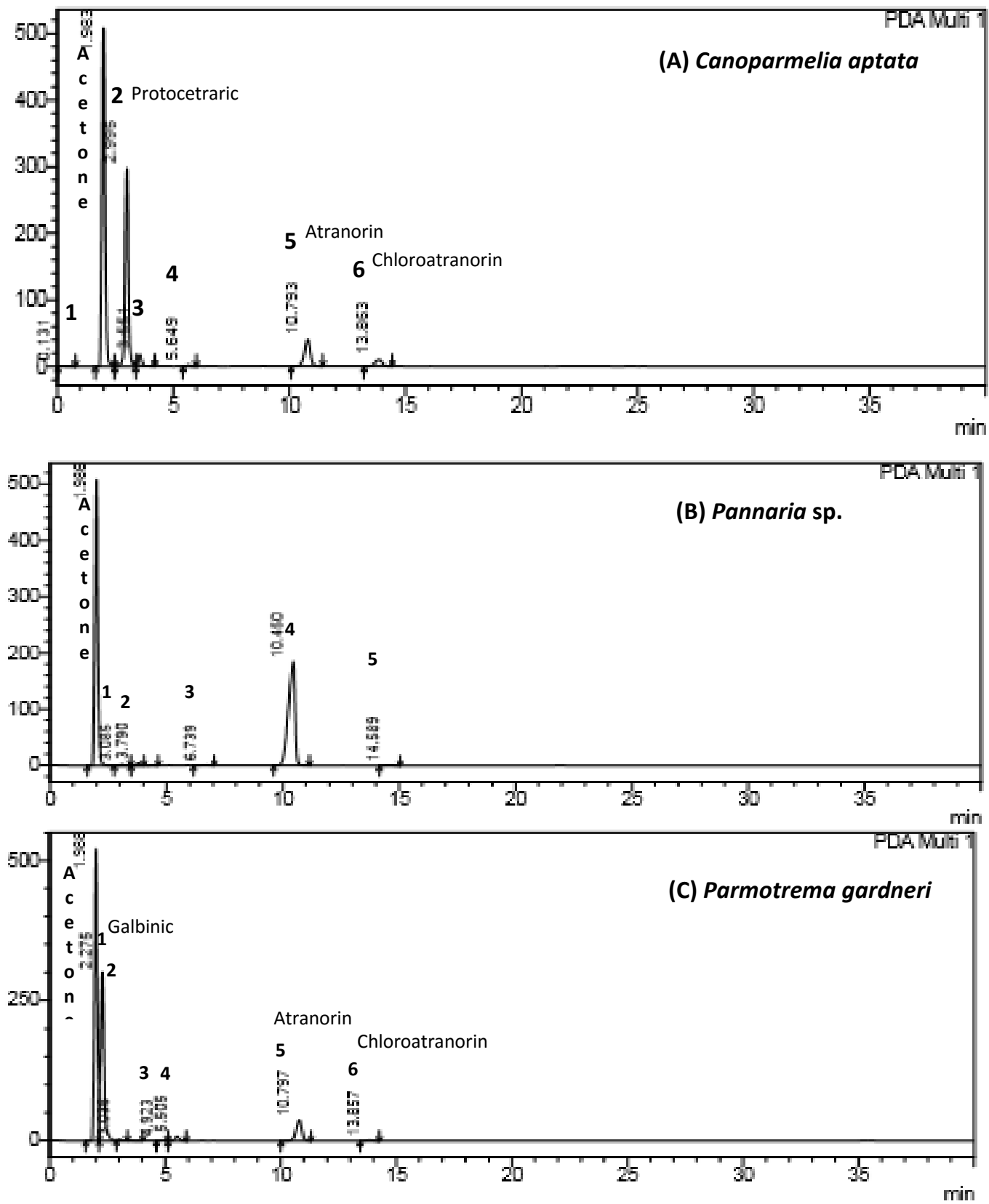

Fig. 3 - HPLC chromatogram of the lichen acids detected in the thallus of the collected corticolous lichens. Some lichen metabolites could not be identified.

The antibacterial, antioxidant, and cytotoxic activities of the acetone extracts of $C$. aptata, Pannaria sp., and $P$. gardneri are reported herein (Table 1). For the antimicrobial activities, $P$. gardneri exhibited the highest inhibitory activity against $P$. aeruginosa with $19 \mathrm{~mm}$ ZOI and against $S$. aureus with $15 \mathrm{~mm}$ ZOI (Fig. 4). P. gardneri also showed cytotoxicity against AGS $\left(\mathrm{IC}_{50}=12.29\right.$ $\mu \mathrm{g} / \mathrm{mL})$ and $\mathrm{A} 549\left(\mathrm{IC}_{50}=20.24 \mu \mathrm{g} / \mathrm{mL}\right)$. Of the three lichen extracts, C. aptata exhibited partial activity against $S$. aureus, but with the least cytotoxicity of $\mathrm{IC}_{50}$ at $167.90 \mu \mathrm{g} / \mathrm{mL}$ for AGS and 200 $\mu \mathrm{g} / \mathrm{mL}$ for A549. However, it was also worth noting that $P$. gardneri had an $\mathrm{IC}_{50}$ of $66.25 \mu \mathrm{g} / \mathrm{mL}$ and Pannaria sp. with an $\mathrm{IC}_{50}$ of $30.26 \mu \mathrm{g} / \mathrm{mL}$, having no cytotoxicity against the normal cell line MDCK. This was further supported by the calculation of the selectivity index values of 1.0-1.19 for C. aptata, 1.72-2.12 for Pannaria sp., and 0.81-3.28 for P. gardneri. However, for the antioxidant assay, the extracts yielded low radical scavenging activity of less than $40 \%$ and generated low amounts of $\mathrm{FeSO}_{4}$ per milligram sample (Table 1). 
Table 1 Antibacterial, antioxidant and cytotoxic activities of the acetone extracts of the corticolous lichens $C$. aptata, Pannaria sp. and P. gardneri.

\begin{tabular}{|c|c|c|c|c|c|c|c|c|c|}
\hline \multirow[b]{2}{*}{$\begin{array}{l}\text { Lichen } \\
\text { Extracts }\end{array}$} & \multicolumn{3}{|c|}{$\begin{array}{c}\text { Antibacterial Assay } \\
\text { Zone of Inhibition in mm } \\
(200 \mu \mathrm{g} / \text { disk })^{\mathrm{a}}\end{array}$} & \multicolumn{2}{|c|}{ Antioxidant Assay } & \multicolumn{3}{|c|}{$\begin{array}{l}\text { Cytotoxicity Assay } \\
\operatorname{IC}_{50}(\mu \mathrm{g} / \mathrm{mL})^{\mathrm{b}}\end{array}$} & \multirow{2}{*}{$\begin{array}{l}\text { Selectivity } \\
\text { Index } \\
(\text { SI })^{\mathrm{g}}\end{array}$} \\
\hline & $\begin{array}{c}\text { S. } \\
\text { aureus }\end{array}$ & $\begin{array}{c}P . \\
\text { aeruginosa }\end{array}$ & $\begin{array}{l}E . \\
\text { coli }\end{array}$ & $\begin{array}{c}\% \mathrm{RSA}^{\mathrm{c}} \\
(500 \\
\mathrm{ppm})\end{array}$ & $\begin{array}{c}\text { ppm } \\
\mathrm{FESO}_{4} \\
\text { (per mg } \\
\text { sample) }\end{array}$ & $\mathrm{AGS}^{\mathrm{d}}$ & A $549^{e}$ & $\mathrm{MDCK}^{\mathrm{f}}$ & \\
\hline $\begin{array}{l}\text { Canoparmelia } \\
\text { aptata }\end{array}$ & 13 & 9 & 10 & 26.07 & 24.84 & 167.90 & 200 & 200 & $1.0-1.19$ \\
\hline Pannaria sp. & 9 & 12 & 0 & 26.50 & 28.29 & 14.27 & 17.50 & 30.26 & $1.72-2.12$ \\
\hline $\begin{array}{l}\text { Parmotrema } \\
\text { gardneri }\end{array}$ & 15 & 19 & 0 & 36.04 & 21.75 & 12.29 & 20.24 & 66.35 & $0.81-3.28$ \\
\hline Gentamycin & - & 30 & - & - & - & - & - & - & - \\
\hline Ampicillin & 23 & - & - & - & - & - & - & - & - \\
\hline Tetracyclin & - & - & 24 & - & - & - & - & - & - \\
\hline Catechin & - & - & - & 81.84 & 950.48 & - & - & - & - \\
\hline
\end{tabular}

${ }^{\mathrm{a}}$ Assessment of ZOI: inactive $(<10 \mathrm{~mm})$, partially active $(10-13 \mathrm{~mm})$, active $(14-19 \mathrm{~mm})$, very active $(>19 \mathrm{~mm})($ Quinto $\&$ Santos 2005). T-test showed significant differences between ZOI of the test extracts and the control antibiotics at $\mathrm{p}<0.01$.

${ }^{\mathrm{b}}$ Assessment of $\mathrm{IC}_{50}$ : Significant activity against cancer cell lines is at $<30 \mu \mathrm{g} / \mathrm{mL}$ (Suffness \& Pezzuto, 1990).

${ }^{\mathrm{c}} \mathrm{RSA}$ - Radical Scavenging Activity

${ }^{\mathrm{d}}$ Human Gastric Adenocarcinoma, ${ }^{\mathrm{e}}$ Human Lung Carcinoma, ${ }^{\mathrm{f}}$ Madin Darby Canine Kidney

${ }^{\mathrm{g}} \mathrm{SI}=\mathrm{IC}_{50}$ of extract against normal cell line / $\mathrm{IC}_{50}$ of extract against cancer cell line, SI > 2.0 selective (Badisa et al. 2009).

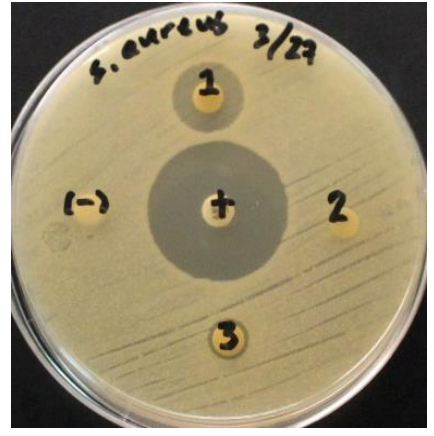

A

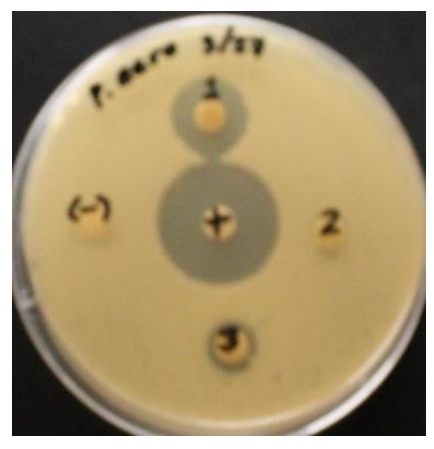

B

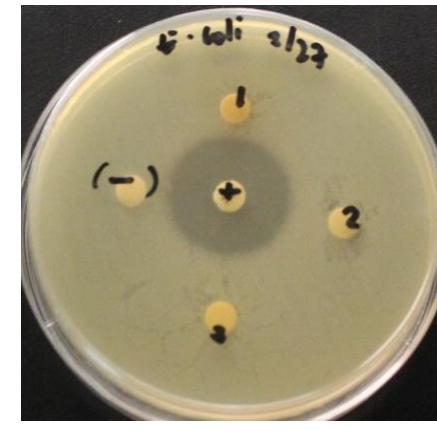

C

Fig. 4 - Zones of inhibition (ZOI) exhibited by the lichen extracts of Parmotrema gardneri (1), Pannaria sp. (2), and Canoparmelia aptata (3) against Staphylococcus aureus (A), Pseudomonas aeruginosa (B), and Escherichia coli (C). Positive controls were ampicillin (S. aureus), gentamycin ( $P$. aeruginosa), and tetracycline (E. coli). Acetone was the negative control.

\section{Discussion}

Similar with other lichen types, the identification of the foliose lichens does not solely rely on the morphological data. The chemical, distributional and ecological characteristics can also be considered. Moreover, with the vast development of other laboratory techniques, the molecular approach also plays an important role in identifying and delimiting a particular lichen species. In this study, three foliose lichens were identified as Canoparmelia aptata, Pannaria sp., and Parmotrema gardneri. The genus Canoparmelia is widely distributed, with 55 species reported worldwide occurring in both tropical and temperate countries (Jayalal et al. 2012). For instance, 15 species of Canoparmelia were identified in Australia, generally occurring as corticolous and saxicolous lichens on subtropical and tropical forests and woodlands (Elix 1994). Furthermore, six species of Canoparmelia have been reported in South Korea, which also includes C. aptata (Jayalal et al. 2012). In this study, the 
morphoanatomical and chemical characterization of the collected lichen $C$. aptata was consistent with the descriptions of Jayalal et al. (2012). C. aptata was previously reported in the Philippines (Elix et al. 2002). Furthermore, the identity of $C$. aptata (E2LS1-02) was also confirmed with a bootstrap support of $100 \%$. The lichen genus Pannaria, on the other hand, belongs to the well-studied family Pannariaceae (Paz-Bermúdez et al. 2008). Taxonomical revisions of the genus under this family have been the primary focus of most studies. In fact, the use of molecular methods in the taxonomy of Pannariaceae resulted in the recent revision of some previously identified genera under this family (Elvebakk et al. 2016). In this study, the Pannaria sp. (E3LS01-02) could only be placed within the Pannaria clade as the bootstrap support was low (Fig. 2).

The genus Parmotrema comprises of approximately 350 species, which mostly occur in the tropical regions of the world (Kukwa et al. 2012, Michlig et al. 2015). In this study, P. gardneri has been identified based solely on its morphological characteristics. Although molecular identification has been employed, PCR amplification of the target genes was not successful. The identity of this species was therefore confirmed based on published identification keys of Aptroot (2009) and McCune (2012).

Since the current challenge for pharmaceutical industries lies on the discovery of new sources of drugs, lichens are undeniably one of the best options. It has been established that lichens produce a plethora of bioactive secondary metabolites (Nash III 1996). In fact, lichen-derived products and their antibiotic properties are of special interest to scientists, since $50 \%$ of all lichens have been reported to exhibit antibiotic properties (Zambare \& Christopher 2012). Nevertheless, relatively few studies on the biological activities of corticolous lichens have been done in the Philippines. In this study, three species of corticolous lichens were subjected to three different assays: antibacterial, cytotoxicity and antioxidant (Table 1). For the antibacterial assay, $P$. gardneri was the most active against $S$. aureus and $P$. aeruginosa. The antibacterial properties of lichens can be attributed to the presence of active lichen substances (Zambare \& Christopher 2012). For instance, depsides and depsidones are the most numerous classes of secondary metabolites in lichens and have been proven effective against various bacteria (Kosanić \& Ranković 2015). Atranorin, a depside, has been identified in C. aptata and $P$. gardneri, thus, inhibition against the test bacteria is expected. This is also consistent with the results of several researches on P. gardneri, revealing its potent antimicrobial activities (Sati \& Joshi 2011, Chauhan \& Abraham 2013). Lichen substances were also found active against various Gram-negative microorganisms such as E. coli, Aeromonas, Pseudomonas, and Proteus sp., to name a few (Zambare \& Christopher 2012). In this study, C. aptata also inhibited the test bacterium E. coli, albeit only partially active (Table 1 ).

Cancer is one of the deadliest diseases worldwide (Global Burden of Disease Cancer Collaboration 2015). Similar with antibacterial activities, lichens have offered plausible solution to combat cancer cells. In this study, P. gardneri have once again showed promising results, i.e., exhibiting the highest cytotoxicity against AGS and A549 cancer cells (Table 1). Some lichen constituents have been studied for their anticancer properties (Kosanić \& Ranković 2015). For instance, the depsidone pannarin exhibited anticancer activities by inducing cell death in human prostate carcinoma DU-145 cells (Kosanić \& Ranković 2015). Atranorin, which was also detected in this study, was also active against nine human cancer cell lines (Backorova et al. 2011). Interestingly, lecanoric acid from $P$. tinctorum also exhibited anticancer activities against larynx carcinoma, breast carcinoma, kidney carcinoma and murine melanoma cell lines (Kosanić \& Ranković 2015).

Currently, the known contributing factor to over a hundred of diseases is the imbalance between intracellular antioxidants and intracellular reactive oxygen species or the so-called oxidative stress (Mitrović et al. 2011). Interestingly, a strong antioxidant power of some lichen species has been evaluated (Mitrović et al. 2011, Paudel et al. 2012). In contrast, a low antioxidant activity was detected in all of the three lichen samples (Table 1). Nevertheless, this study adds information on the antioxidant activities of corticolous lichens.

\section{Acknowledgments}

EE de Jesus expresses her earnest gratitude to the Southern Luzon State University, the Department of Science and Technology-Philippine Council for Health Research and Development 
(DOST-PCHRD) for the graduate scholarship, the Philippine Council for Industry, Energy, and Emerging Technology Research and Development (PCIEERD) for the BCDA training grant, the UST Research Center for Natural and Applied Sciences (RCNAS) for providing the facility, and the Korean Lichen Research Institute (KOLRI), the College of Pharmacy, and the Research Institute of Life and Pharmaceutical Sciences at the Sunchon National University in Korea for the assistance in the bioassays.

\section{References}

Abichandani M, Nahar L, Singh P, Chitnis R, Nazemiyeh H, Delazar A, Sarker DS. 2010 Antibacterial and free radical scavenging properties of Stachys schtschegleevii (Lamiaceae). Archives of Biological Sciences 62(4), 941-945.

Aptroot A. 2009 - Keys to the macrolichens and checklist of the lichens and lichenicolous fungi of New Guinea. Accessed in www.bgbm.fu-berlin.de/sipman/Zschackia/png\%20macrokey.

Backorova M, Backor M, Mikes J, Jendzelovsky R, Fedorocko P. 2011 - Variable responses of different human cancer cells to the lichen compounds parietin, atranorin, usnic acid and gyrophoric acid. Toxicology In Vitro 25(1), 37-44.

Badisa RB, Darling-Reed SF, Joseph P, Cooperwood JS, Latinwo LM, Goodman CB. 2009 - Selective cytotoxic activities of two novel synthetic drugs on human breast carcinoma MCF-7 cells. Anticancer Research 29(8), 2993-2996.

Chauhan R, Abraham J. 2013 - In vitro antimicrobial potential of the lichen Parmotrema sp. extracts against various pathogens. Iranian Journal of Basic Medical Sciences 16, 882-885.

Culberson CF. 1972 - Improved conditions and new data for the identification of lichen products by a standardized thin-layer chromatographic method. Journal of Chromatography 72, 113-125.

Deacon J. 2006 - Fungal Biology. ${ }^{4 \text { th }}$ Ed. Blackwell Publishing Company, USA.

Elix JA, Bawingan PA, Flores YG. 2002 - A new species and further new records in the lichen family Parmeliaceae (Ascomycotina) from the Philippines. Mycotaxon 81, 251-256.

Elix JA. 1994 - Parmelinella. In: Flora of Australia. Volume 55. Lichens - Lecanorales 2, Parmeliaceae. Orchard AE, Grgurinovic C. Eds. Australian Government Publishing Service, Canberra.

Elvebakk A, Hong SG, Park CH, Robertsen EH, Jorgensen M. 2016 - Gibbosporina, a new genus for foliose and tripartite, palaeotropic Pannariaceae species previously assigned to Psoroma. The Lichenologist 48(1), 13-52.

Gascon CN, Garcia RC, Beltran FN, Faller WC, Agudilla MAR. 2013 - Biodiversity assessment of Mt. Banahaw de Dolores, Philippines. Asian Journal of Biodiversity 4, $23-45$.

Gasi KMP, Brenesel M, Djeurndic E, Sakaic MN, Canadi JJ, Daljev JJ, Ambruster T, Andric S, Sladic DM, Bozic T, Novakovic I, Juranic ZD. 2007 - Synthesis and biological evaluation of some 17picolyl and 17-picolynylidene androst-5-ene derivatives. Steroids 72 (1), 31-40.

Global Burden of Disease Cancer Collaboration. 2015 - The global burden of cancer 2013. JAMA Oncology 1(4), 505-527.

Jayalal U, Santosh J, Oh SO, Park JS, Hur, JS. 2012 - Notes on species of the lichen genus Canoparmelia Elix \& Hale in South Korea. Mycobiology 40(3), 159-163.

Kosanić M, Ranković B. 2015 - Lichen secondary metabolites as potential antibiotic agents. In: Lichen Secondary Metabolites Bioactive Properties and Pharmaceutical Potential. Ranković B. Ed. Springer International Publishing, Switzerland.

Kukwa M, Bach K, Sipman HJM, Flakus A. 2012 - Thirty-six species of the lichen genus Parmotrema (Lecanorales, Ascomycota) new to Bolivia. Polish Botanical Journal 57(1), 243-257.

Kumar PSV. 2010 - Studies on antibacterial, antihelminthic and antioxidant activities of a macrolichen Parmotrema pseudotinctorum (des. Abb.) Hale (Parmeliaceae) from Bhadara wildlife sanctuary, Karnataka. International Journal of PharmTech Research 2(2), 1207-1214. 
Lücking R, Archer AW, Aptroot A. 2009 - A worldwide key to the genus Graphis (Ostropales: Graphidaceae). The Lichenologist 41(4), 363-452.

McCune, B. 2012 - Key to the Lichen Genera of the Pacific Northwest. Department of Botany \& Plant Pathology, Oregon State University, Corvallis, Oregon.

Michlig A, Rodríguez MP, Ferraro LI. 2015 - New record and distribution map of Parmotrema rubifaciens (Parmeliaceae, Ascomycota) in the Neotropics. The Journal of Biodiversity 11(5), $1-5$.

Mitrović T, Slaviša S, Cvetković V, Tošić S, Stanković M, Radojević I, Stefanović O, Čomić L, Dačić D, Ćurčić M, Marković S. 2011 - Antioxidant, antimicrobial and antiproliferative activities of five lichen species. International Journal of Molecular Sciences 12, 5428-5448.

Molnar K, Farkas, E. 2010 - Current results on biological activities of lichen secondary metabolites: A review. Zeitschrift für Naturforschung 65, 157-173.

Nash III TH. 1996 - Lichen Biology. Cambridge University Press, New York USA.

Nayaka S. 2014 - Methods and techniques in collection, preservation and identification of lichens in plant taxonomy and biosystematics - Classical and modern methods. New India Publishing Agency, India.

Nguyen TT, Yoon S, Yang Y, Lee HB, Oh SO, Jeong MH, Kim JJ, Yee ST, Cris F, Moon C, Lee KY, Kim KK, Hur JS, Kim H. 2014 - Lichen secondary metabolites in Flavocetraria cucullata exhibit anticancer effects on human cancer cells through the induction of apoptosis and suppression of tumorigenic potentials. PLOS ONE 9(10), 111-575.

Omarsdóttir S, Freysdottir J, Olafsdottir ES. 2007 - Immunomodulating polysaccharides from the lichen Thamnolia vermicularis var. subuliformis. Phytomedicine 14, 179-184.

Orange A, James PW, Whiten FJ. 2001 - Microchemical Methods for the Identification of Lichens. British Lichen Society, London.

Park SY, Jang SH, Oh SO, Kim JA, Hur, JS. 2014 - An easy, rapid, and cost-effective method for DNA extraction from various lichen taxa and specimens suitable for analysis of fungal and algal strains. Mycobiology 42(4), 311-316.

Paudel B, Bhattarai HD, Pandey DP, Hur JS, Hong SG, Kim II-C, Yim JH. 2012 - Antioxidant, antibacterial activity and brine shrimp toxicity test of some mountainous lichens from Nepal. Biological Research 45, 387-391.

Paz-Bermúdez G, Carballal R, de Silanes EL. 2008 - The genus Fuscopannaria P.M. Jørg. (Pannariaceae, lichenized Ascomycota) in the Iberian Peninsula. Candollea 63(2), 269-280.

Quinto EA, Santos MG. 2005 - Microbiology. In: A Guidebook to Plant Screening: Phytochemical and Biological, $2^{\text {nd }}$ Ed. Guevarra BQ. Ed. University of Santo Tomas Publishing House, Philippines.

Ranković B, Kosanić M, Stanojković TP. 2011 - Antioxidant, antimicrobial and anticancer activity of the lichens Cladonia furcata, Lecanora atra and Lecanora muralis. BMC Complementary and Alternative Medicine 11(97), 1-8.

Santiago KAA, Boricano JNC, Canal JN, Marcelo DMA, Perez MCP, dela Cruz TEE. 2010 Antibacterial activities of fruticose lichens collected from selected sites in Luzon Island, Philippines. Philippine Science Letters 3(2), 18-29.

Santiago KAA, Sangvichien E, Boonpragob K, dela Cruz TEE. 2013 - Secondary metabolic profiling and antibacterial activities of different species of Usnea collected in Northern Philippines. Mycosphere 4(2), 267-280.

Sati SC, Joshi S. 2011 - Antibacterial activity of the Himalayan lichen Parmotrema nilgherrense extracts. British Microbiology Research Journal 1(2), 26-32.

Styers DM, Chappelka AH. 2009 - Urbanization and atmospheric deposition: Use of bioindicators in determining patterns of land-use change in West Georgia. Water Air Soil Pollution 200, 371386.

Suffness M, Pezzuto, JM. 1990 - Assays related to cancer drug discovery. In: Methods in Plant Biochemistry: Assays for Bioactivity. Hostettmann K. Ed. Academic Press, London. 
Süleyman H, Odabasoglu F, Aslan A, Cakir A, Karagoz Y, Gocer F, Halici M, Bayir Y. 2003 - Antiinflammatory and antiulcerogenic effects of the aqueous extract of Lobaria pulmonaria (L.) Hoffm. Phytomedicine 10, 552-557.

Thell A, Crespo A, Divakar PK, Kärnefelt I, Leavitt SV, Lumbsch HT, Mark RD. 2012 - A review of the lichen family Parmeliaceae - History, phylogeny and current taxonomy. Nordic Journal of Botany 30, 641-664.

White TJ, Bruns TD, Lee SB, Taylor JW. 1990 - Amplification and direct sequencing of fungal ribosomal RNA genes for phylogenetics. In: PCR Protocols - A Guide to Methods and Applications. Innis MA, Gelfand DH, Sninsky JJ, White TJ. Eds. Academic Press, San Diego.

Zambare VP, Christopher LP. 2012 - Biopharmaceutical potential of lichens. Pharmaceutical Biology 50(6), 778-798. 